\title{
Effects of a clear-cut on the in situ nitrogen mineralisation and the nitrogen cycle in a 67-year-old Douglas-fir (Pseudotsuga menziesii (Mirb.) Franco) plantation
}

\author{
Jean-Hugues JuSSY, Jacques RANGER*, Séverine BIENAIMÉ, Etienne DAMBRINE \\ INRA Centre de Nancy, Unité Biogéochimie des Écosystèmes Forestiers, 54280 Champenoux, France
}

(Received 5 February 2003; accepted 20 August 2003)

\begin{abstract}
In situ net nitrogen mineralisation, deposition, uptake and leaching fluxes were determined in a 67-year-old Douglas-fir (Pseudotsuga menziesii (Mirb.) Franco) plantation in the Beaujolais mountains. Measurements were performed during five years before the clear-cut of the stand and two years after the clear-cut. Deposition and mineralisation of $\mathrm{N}$ decreased after the harvest. The drastic decrease in tree $\mathrm{N}$ uptake was counteracted by the developing understorey vegetation. Microbial immobilisation, favoured by the input of organic matter and the increase in temperature, was probably the cause of a decrease in the net mineralisation of $\mathrm{N}$. Leaching of mineral $\mathrm{N}$ at $15 \mathrm{~cm}$ depth decreased after the harvest. However, fluxes of $\mathrm{Mg}$ and $\mathrm{Ca}$ leached at $60 \mathrm{~cm}$ depth did not vary after the harvest.
\end{abstract}

nitrogen cycle / clear-cut / Pseudotsuga menziesii / leaching / soil

Résumé - Effet de la coupe à blanc d'une plantation de Douglas (Pseudotsuga menziesii (Mirb.) Franco) de 67 ans, sur la production in situ d'azote minéral et sur le cycle de l'azote. La minéralisation nette, les dépôts, l'absorption et le drainage d'azote ont été mesurés in situ dans une plantation de Douglas (Pseudotsuga menziesii (Mirb.) Franco) de 67 ans, située sur sol acide dans les monts du Beaujolais. Les mesures ont été effectuées pendant cinq ans avant la coupe à blanc du peuplement, puis pendant 2 ans après la coupe. Les dépôts d'azote atmosphérique et la minéralisation de l'azote diminuent après la récolte. La diminution du prélèvement d'azote par les racines est limitée par le développement de la végétation herbacée. L'immobilisation microbienne de l'azote, favorisée par les apports de matière organique et l'augmentation de la température, est supposée être la cause de cette diminution de la minéralisation nette. En conséquence, le drainage d'azote minéral à $15 \mathrm{~cm}$ de profondeur est réduit après la coupe. Toutefois, les flux de $\mathrm{Mg}$ et $\mathrm{Ca}$ dans les solutions gravitaires à $60 \mathrm{~cm}$ de profondeur ne sont pas modifiés après la coupe.

cycle de l'azote / coupe à blanc / Pseudotsuga menziesii / drainage / sol

\section{INTRODUCTION}

Forest clear-cutting leads to a disruption of the biogeochemical cycle of elements. It implies large changes in the physical conditions of the soil, especially in the temperature and in the moisture regime [35], and consequently in the amount of fresh organic matter accumulated on the forest floor. Hence, it may have long-lasting effects on nutrient deposition (including dry deposition and canopy interaction), on uptake by the vegetation (trees and understorey vegetation), on return of nutrients to the soil by litterfall, on microbial activity and therefore on nutrient availability [22].

The potential influence of $\mathrm{N}$ on the diversity and the stability of ecosystems [5, 36, 80] and on soil acidification, through deposition and leaching processes is well documented [21]. It is therefore important to understand how the different fluxes of the nitrogen cycle react to the changes induced by clear-cutting.
It is generally believed that clear-cutting, by stopping $\mathrm{N}$ uptake by trees and decreasing total deposition, increases $\mathrm{N}$ availability in the soil $[63,74,91]$ and therefore potentially the leaching of nitrates when produced [24]. On the other hand, the growth of understorey vegetation as well as the increase in the availability of nutrients which favours microbial immobilisation [22, 49, 79] may limit the leaching.

Douglas-fir (Pseudotsuga menziesii (Mirb.) Franco) is one of the main species used for afforestation in France, with a total area of about $350000 \mathrm{ha}$. We have studied in detail the impact of the introduction of this non-native species on soil fertility $[41,54-56,67,68,70]$ and we are now focusing on the impact of harvesting.

The present study was designed (i) to quantify the major $\mathrm{N}$ fluxes, and especially the in situ net production of mineral $\mathrm{N}$ (i.e. mineralisation and nitrification) in a 67-year-old Douglasfir stand, and (ii) to compare them before and after felling, in

\footnotetext{
* Corresponding author: ranger@nancy.inra.fr
} 
Table I. Main physico-chemical characteristics of the soil of the site before the harvest [14].

\begin{tabular}{|c|c|c|c|c|c|c|c|c|c|c|c|c|c|c|c|}
\hline \multirow[t]{2}{*}{ Hor. } & \multirow{2}{*}{$\begin{array}{l}\text { Depth } \\
(\mathrm{cm})\end{array}$} & \multirow{2}{*}{$\mathrm{pH}_{\left(\mathrm{H}_{2} 0\right)}$} & Clay & Silt & Sand & $\mathrm{OM}$ & $\mathrm{N}$ & \multirow[t]{2}{*}{$\mathrm{C}: \mathrm{N}$} & $\mathrm{Ca}$ & $\mathrm{Mg}$ & $\mathrm{K}$ & $\mathrm{Na}$ & $\mathrm{Al}$ & CEC & \multirow{2}{*}{$\begin{array}{l}\text { BS } \\
(\%)\end{array}$} \\
\hline & & & \multicolumn{3}{|c|}{$(\%)$} & \multicolumn{2}{|c|}{$(\%)$} & & \multicolumn{6}{|c|}{$\mathrm{cmol}_{\mathrm{c}} \cdot \mathrm{kg}^{-1}$} & \\
\hline $\mathrm{A}_{1}$ & $0-17$ & 4.3 & 24 & 39 & 37 & 6.3 & 0.30 & 12.3 & 0.30 & 0.10 & 0.23 & 0.03 & 5.7 & 14.6 & 4.5 \\
\hline $\mathrm{A}_{2}$ & $17-37$ & 4.4 & 26 & 45 & 29 & 3.4 & 0.17 & 11.8 & 0.10 & 0.03 & 0.11 & 0.03 & 4.4 & 10.2 & 2.6 \\
\hline (B) & $37-60$ & 4.4 & 27 & 33 & 36 & 1.0 & 0.06 & 9.6 & 0.10 & 0.02 & 0.11 & 0.02 & 3.9 & 6.9 & 3.5 \\
\hline (B)/C & $60-90$ & 4.5 & 14 & 39 & 47 & 0.2 & 0.02 & 7.3 & 0.10 & 0.02 & 0.10 & 0.02 & 4.0 & 6.0 & 4.1 \\
\hline
\end{tabular}

order to evaluate the effects of stand harvesting on future site productivity. As uptake of nitrogen is assumed to decrease considerably after harvest, nitrate leaching might be enhanced. It has already been observed that the nutrient budgets in this site, which were strongly negative in younger stands, become equilibrated in the older stand $[17,56]$. It is therefore of paramount interest to look at the consequences of harvest on the dynamics of nutrients and on the budgets calculated for the whole rotation.

\section{MATERIALS AND METHODS}

\subsection{Site description}

The 67-year-old Douglas-fir (Pseudotsuga menziesii (Mirb.) Franco) stand was located in a long-term experimental site in the Aiguillettes forest in the Beaujolais Mounts, in the north-eastern part of the Massif Central (France). The climate is mountainous with an oceanic influence. The altitude is about $750 \mathrm{~m}$. The mean annual temperature is $9{ }^{\circ} \mathrm{C}$ and mean annual precipitation is $1000 \mathrm{~mm}$ (38 days of snow) evenly distributed throughout the year (data from the Meteorological Station of Tarare-les-Sauvages, $50 \mathrm{~km}$ south of the site [53]).

The stand was the first rotation afforested directly from abandoned cropland [69]. The slope was gentle, always $<5 \%$. The general characteristics of the stand [68] classified it as fertility class 1 for the northeast Massif Central, according to Decourt's typology [20], with an average height of $40 \mathrm{~m}, \mathrm{aCBH}$ of $166 \mathrm{~cm}, 206$ trees per ha and a current annual wood production of $15 \mathrm{~m}^{3} \cdot \mathrm{ha}^{-1} \cdot \mathrm{yr}^{-1}$ in 1998 [70]. Some brambles (Rubus fructicosus) were growing sparsely before the harvest and more vigorously after. All understorey species were annually identified according to Braun-Blanquet [10] one year before (August 1997) and one year after (September 1999) clear-cutting (Picard, unpublished data). After harvesting of stems, all residues (twigs and needles) were left on the ground and were manually stacked. In order to protect the experimental design, no tractors were used as they would be in a real site preparation.

The bedrock was a tuff from the Upper Visean (Carboniferous), relatively rich in $\mathrm{Ca}$ and $\mathrm{Mg}$ [23]. However, the specific weathering process of the amorphous phase of this compacted bedrock led to a soil with fine fractions poor in base cations. The soil was a Typic Dystrochrept according to the Soil Taxonomy [75]. The texture of the upper horizons was loamy (40-45\% of silt in the two first horizons, Tab. I) and the clay content was relatively low ( $24 \%$ in the first horizon and only $14 \%$ in the deepest). $\mathrm{pH}$ was also relatively low (it increased from 4.3 on surface to 4.5 in depth). Aluminium filled the largest part of the cation exchange capacity (CEC) and the "base" saturation (BS) was low for the whole profile $(<15 \%)$. The humus layer was of the moder type with a thin LF sublayer, roughly $1 \mathrm{~cm}$ deep. The $\mathrm{C}: \mathrm{N}$ ratio of the FH sublayer was 24 [68]. Chemical characteristics of the soil were reassessed on 32 pits sampled before (September 1998) and after the harvest (September 1999 and September 2000) according to the methodology previously used by Ranger et al. [68].

\subsection{Stand and understorey biomass}

Needle biomass ( 1 year old or more), branches (1 year old or more) and bole (stemwood and stembark) biomass, stump and root ( $>2 \mathrm{~mm}$ diameter) biomass, and associated mineral contents were measured on twelve trees distributed throughout all the girth classes defined from the inventory [54, 56, 67]. Litterfall was measured from 15 litter traps, collected every three months (see Ranger et al. [71] for litter trap design). Annual increment and immobilisation of nutrients were calculated from mathematical models integrating biomass and nutrient contents [67].

Above-ground understorey biomass was determined 2 months before clear-cutting in September 1998, and ten months later in September 1999 by destructive sampling of vegetation on nineteen-1 $\mathrm{m}^{2}$ plots (Picard, unpublished data).

\section{3. $\mathrm{N}$ input-output fluxes}

The experiment was carried out from April 1993 to October 2000. The harvest of the stand took place in November 1998. The data base contained measurements taken five and a half years before harvest and two years after harvest.

$\mathrm{N}$ deposition to the soil was collected by a set of three throughfall collectors, each composed of double gutters $(2.17 \mathrm{~m} \times 0.12 \mathrm{~m}$ each $)$ and placed to cover the variations in the stand canopy [54]. During winter they were replaced by plastic bags placed in buckets $(0.39 \mathrm{~m}$ diameter) $1.3 \mathrm{~m}$ above the soil level. Stemflow was sampled using plastic collars placed around ten tree stems evenly distributed through out the girth classes (two of them remained connected during winter months).

Seepage water was collected in four zero-tension plate lysimeters $(0.4 \mathrm{~m} \times 0.3 \mathrm{~m})$, which were placed at $15,30,60$ and $120 \mathrm{~cm}$ depth [54] and connected to plastic containers. Throughfall and seepage water containers and the two winter stemflow containers were placed in closed pits and protected against freezing, light and variations in temperature [54]. Containers were sampled every four weeks. Dry deposition of $\mathrm{N}$ was estimated before the harvest assuming that $\mathrm{N}: \mathrm{S}$ ratio in rainfall and dry deposition were similar [70, 82]. Canopy uptake was calculated as follows:

\section{Canopy uptake $=$ throughfall $-($ rainfall + dry deposition $)$.}

After filtering the samples ( $0.45 \mu \mathrm{m}$ porosity), $\mathrm{NH}_{4}^{+}-\mathrm{N}$ and $\mathrm{NO}_{3}^{-}-\mathrm{N}$ concentrations were measured colorimetrically (autoanalyser II Technicon, Dublin before 1996 and TRAACS 2000 after 1996). Inputs and drainage of mineral $\mathrm{N}$ were calculated as the product of the water flux (throughfall and soil leaching respectively) and $\mathrm{NO}_{3}^{-}-\mathrm{N}$ and $\mathrm{NH}_{4}^{+}-\mathrm{N}$ concentrations in solutions. Drainage of water was calculated with a water model using the climatic data of the site, stand structure and soil water retention curves [28, 84]. Potential evapotranspiration was computed from climatic parameters (aerial and soil temperature and moisture) continuously recorded at the site. Some parameters of the model i.e. interception by canopy and evaporation at the soil level, were modified after the harvest to take into account the new conditions caused 
by the harvest. Continuous soil moisture measurements were made from 1997 to 2000 using a TDR-system (Trase from Soilmoisture Equipment Corp., Santa Barbara, CA, USA).

\subsection{N mineralisation, nitrification and uptake: in situ incubation}

\subsubsection{Experimental design}

$\mathrm{N}$ fluxes (i.e. nitrification, mineralisation and root uptake) were assessed by incubating in situ soil cores and comparing $\mathrm{N}$ contents in incubated and non incubated soil. Cores of undisturbed soil were isolated and incubated in twelve stainless steel cylinders, $7.6 \mathrm{~cm}$ inner diameter, $15 \mathrm{~cm}$ long $[46,65]$. Cylinders were placed in lines (about $40 \mathrm{~cm}$ between two cylinders) and two lines of successive incubations were separated by approximately $30 \mathrm{~cm}$. As root uptake was suppressed in the cylinders, mineral $\mathrm{N}$ contents were different inside and outside the cylinders after incubation. Incubated cores were sampled every four weeks. At each sampling date, nine non-incubated soil cores were also sampled between each incubated cylinder, to assess the mineral $\mathrm{N}$ content of the soil outside the cylinders at the start of the incubation period, which also corresponded to the content at the end of the previous incubation period.

The leaching of $\mathrm{NO}_{3}^{-}$(from October 1993) and $\mathrm{NH}_{4}^{+}$(from April 1996) in the cylinders (without root uptake) was measured by inserting nylon bags containing exchange resin $[37,64]$ in the bottom of each cylinder. The last centimeter of soil in each cylinder was removed and replaced by a Nylon bag containing $40 \mathrm{~g}$ of resin mixed with $40 \mathrm{~g}$ of glass beads to increase the volume of the bags. Six cylinders containing an anion exchange resin (DOWEX 21K, 20-50 mesh) and six cylinders containing a cation exchange resin (IRN 77, 16-40 mesh) were set up. Before incubation, the anion exchange resin was saturated with $\mathrm{Cl}^{-}$ by a slow percolation of demineralised water followed by $1 \mathrm{M} \mathrm{NaCl}$ (1 L: $100 \mathrm{~g}$ of resin). The cation resin was saturated with $\mathrm{Na}^{+}$by a slow percolation of demineralised water followed by $1 \mathrm{M} \mathrm{HCl}(1 \mathrm{~L}$ : $100 \mathrm{~g}$ of resin) and $1 \mathrm{M} \mathrm{NaOH}(1 \mathrm{~L}: 100 \mathrm{~g}$ of resin) with a final $\mathrm{pH}$ between 6 and 7 .

The specific design was slightly adapted during the course of the experiment. From October 1993 to March 1996, nine cylinders containing only an anion exchange resin bag were used; From April 1996 to September 1996, six cylinders containing an anion resin bag and six cylinders containing a cation resin bag were set up. Finally, at the beginning of October 1996, the quantity of resin in each cylinder was doubled by adding a second bag containing the corresponding resin type, in order to assess the efficiency of each resin type in situ.

\subsubsection{Analyses}

In the field, after removing the LF sub-layer $(1 \mathrm{~cm}$ thick) from soil cores, soil samples were combined, per time period, into three samples of incubated soil and three samples of non-incubated soil. Samples were sieved $(<4 \mathrm{~mm})$ and immediately put in flasks containing $1 \mathrm{M} \mathrm{KCl}$ (40 g moist soil: $200 \mathrm{~mL}$ solution). Soil samples and resin bags were then transferred to the laboratory in a cool box. Soil moisture was determined on a sub-sample dried at $105^{\circ} \mathrm{C}$. Soil mineral $\mathrm{N}$ was extracted in $\mathrm{KCl}$ by centrifugation and filtration of the supernatant after mechanical shaking $(1 \mathrm{~h})$.

Resin bags were rinsed with demineralised water to remove soil particles and adhering organic residues [27]. Rinsing with water had no effect on $\mathrm{N}$ desorption for anionic resins, but desorbed $2 \%$ of the fixed $\mathrm{NH}_{4}-\mathrm{N}$ independently of the fixed amount. The percentage desorbed was taken into account in the final calculation. Bags were opened, air-dried and sieved to separate resin and glass beads. Nitrate and ammonium were extracted by $1 \mathrm{M} \mathrm{NaCl}(4 \mathrm{~g}: 40 \mathrm{~mL}$ dwt: v) after manual shaking, batch contact $(1 \mathrm{~h})$ and filtration. Mineral nitrogen contents in $\mathrm{KCl}$ and $\mathrm{NaCl}$ extracts were measured by colorimetry (using an Autoanalyser II, Technicon, Dublin, or a TRAACS 2000, Bran-Luebbe, Norderstedt, Ger.).

As the amount of $\mathrm{NH}_{4}^{+}-\mathrm{N}$ extracted from the soil varied with the duration of contact with $\mathrm{KCl}$ solution, a set of comparative measurements ( $1 \mathrm{~h}$ vs. 24 or $48 \mathrm{~h}$ ) was taken in the laboratory. As a consequence, amounts of $\mathrm{NH}_{4}^{+} \mathrm{N}$ extracted from soil were divided by 1.5 $(24 \mathrm{~h})$ or $2.38(48 \mathrm{~h})$, depending on the duration of contact between soil and $\mathrm{KCl}$.

We found a highly significant correlation $(P<0.001$, only data before clear-cutting were taken into account) between the amount of ions trapped in the upper resin bag $(\mathrm{x})$ and the amount of ions trapped in the two bags $(\mathrm{y})\left(\mathrm{y}=1.374 \mathrm{x}+329.096, r^{2}=0.73, n=102\right.$, data in $\mu \mathrm{g}$ of mineral $\mathrm{N}$ leached per cylinder). This correlation was applied to the period during which only one resin bag per cylinder had been used to correct leaching values inside the cylinders. We assumed that all the mineral $\mathrm{N}$ leached in the cylinders was caught by the resin bags but we probably underestimated this leaching, as resin fixation efficiency was between 85\% [94] and 99\% [27] in laboratory experiments, according to the leaching rate.

The desorption efficiency of $\mathrm{NH}_{4}^{+}$and $\mathrm{NO}_{3}^{-}$from resins was checked in the laboratory. Empirical relationships between desorbed nitrogen (D) and adsorbed nitrogen (A) were, for anionic resins: $\mathrm{A}=$ $2.363 \mathrm{D}^{0.945}\left(n=30, r^{2}=0.95\right.$, units are $\left.\mu \mathrm{g} \cdot \mathrm{g}^{-1}\right)$; and for cationic resins: $\mathrm{A}=1.887 \mathrm{D}-2.141\left(n=13, r^{2}=0.99\right)$. In rare cases, when $\mathrm{D}<2.414$ A was calculated to be $<D$, which is impossible; in this case, it was assumed that $\mathrm{A}=\mathrm{D}$.

\subsubsection{Calculation of fluxes}

Fluxes were calculated by a set of equations based on mineral $\mathrm{N}$ budgets outside and inside the cylinders. Soil bulk density used for hectare-based calculations was estimated taking the densities of the $0-15 \mathrm{~cm}$ layer of two pits and was $0.53 \mathrm{~kg} \cdot \mathrm{dm}^{-3}$ [53]. We considered that each cylinder was full with $13 \mathrm{~cm}$ of soil because the upper centimeter (fresh litter) and the bottom centimeter were discarded. A set of equations adapted from Raison et al. [65] was used to calculate mineralisation, nitrification and root uptake fluxes:

$\mathrm{T}_{0 \mathrm{i}}=$ initial $\mathrm{NO}_{3}^{-}-\mathrm{N}$ (or $\mathrm{NH}_{4}^{+}-\mathrm{N}$ ) content at the beginning of the incubation period.

$\mathrm{T}_{0 \mathrm{f}}=$ final $\mathrm{NO}_{3}^{-}-\mathrm{N}\left(\right.$ or $\left.\mathrm{NH}_{4}^{+}-\mathrm{N}\right)$ content of the soil outside the cylinders at the end of the incubation period.

$\mathrm{T}_{1}=$ final $\mathrm{NO}_{3}^{-}-\mathrm{N}\left(\right.$ or $\left.\mathrm{NH}_{4}^{+}-\mathrm{N}\right)$ content of the soil inside the cylinders at the end of the incubation period.

For $\mathrm{NO}_{3}^{-}-\mathrm{N}$ :

$\mathrm{T}_{0 \mathrm{fNO} 3}=\mathrm{T}_{0 \mathrm{fiNO} 3}+$ external inputs of $\mathrm{NO}_{3}+$ gross nitrification root uptake of $\mathrm{NO}_{3}$ - microbial immobilisation of $\mathrm{NO}_{3}$ - leaching of $\mathrm{NO}_{3}$ outside the cylinders.

$\mathrm{T}_{1 \mathrm{NH} 3}=\mathrm{T}_{0 \mathrm{iNO} 3}+$ external inputs of $\mathrm{NO}_{3}+$ gross nitrification microbial immobilisation of $\mathrm{NO}_{3}$ - leaching of $\mathrm{NO}_{3}$ inside the cylinders.

Net nitrification $=\mathrm{T}_{1 \mathrm{NO} 3}-\mathrm{T}_{0 \mathrm{NNO} 3}-$ external inputs of $\mathrm{NO}_{3}+$ leaching of $\mathrm{NO}_{3}$ inside the cylinders ${ }^{1}$.

For $\mathrm{NH}_{4}^{+}-\mathrm{N}$ :

$\mathrm{T}_{0 \mathrm{fNH} 4}=\mathrm{T}_{0 \mathrm{iNH} 4}+$ external inputs of $\mathrm{NH}_{4}+$ gross mineralisation - root uptake of $\mathrm{NH}_{4}-$ microbial immobilisation of $\mathrm{NH}_{4}-$ gross nitrification - leaching of $\mathrm{NH}_{4}$ outside the cylinders.

$\mathrm{T}_{1 \mathrm{NH} 4}=\mathrm{T}_{0 \mathrm{iNH} 4}+$ external inputs of $\mathrm{NH}_{4}+$ gross mineralisation microbial $\mathrm{NH}_{4}$ immobilisation - gross nitrification - leaching of $\mathrm{NH}_{4}$ inside the cylinders ${ }^{1}$.

\footnotetext{
${ }^{1}$ Missing data were calculated using the mean of available monthly data for the same period of the year.
} 
Table II. Mean annual temperature $\left({ }^{\circ} \mathrm{C}\right)$ before and after the harvest at different levels. Mean annual temperatures were the means of mean monthly temperatures, calculated with the mean of daily temperature (Tmax - Tmin).

\begin{tabular}{lccccc}
\hline & Air $(1.3 \mathrm{~m}$ above ground $)$ & Litter & $15 \mathrm{~cm}$ depth & $30 \mathrm{~cm}$ depth & $60 \mathrm{~cm}$ depth \\
\hline Before harvest & $9.3 \mathrm{a}$ & $8.3 \mathrm{~b}$ & $8.6 \mathrm{~b}$ & $9.0 \mathrm{~b}$ & $8.9 \mathrm{~b}$ \\
After harvest & $10.1 \mathrm{a}$ & $10.6 \mathrm{a}$ & $10.0 \mathrm{a}$ & $10.4 \mathrm{a}$ & $10.1 \mathrm{a}$ \\
\hline
\end{tabular}

For a given level, different letters show different annual temperatures before and after the harvest $(\alpha=0.05)$.

Table III. Water and mineral nitrogen content in the upper soil layer $(0-15 \mathrm{~cm})$ before and after harvesting, inside and outside the cylinders after a four-week incubation period.

\begin{tabular}{|c|c|c|c|c|c|c|c|c|}
\hline & \multicolumn{2}{|c|}{ Water content $\left(\mathrm{g} \cdot \mathrm{g}^{-1}\right)$} & \multicolumn{2}{|c|}{$\mathrm{NO}_{3}^{-}-\mathrm{N}\left(\mathrm{kg} \cdot \mathrm{ha}^{-1}\right)$} & \multicolumn{2}{|c|}{$\mathrm{NH}_{4}^{+}-\mathrm{N}\left(\mathrm{kg} \cdot \mathrm{ha}^{-1}\right)$} & \multicolumn{2}{|c|}{$\mathrm{NO}_{3}^{-}-\mathrm{N}+\mathrm{NH}_{4}^{+}-\mathrm{N}\left(\mathrm{kg} \cdot \mathrm{ha}^{-1}\right)$} \\
\hline & Inside & Outside & Inside & Outside & Inside & Outside & Inside & Outside \\
\hline \multirow[t]{2}{*}{ Before harvest } & $0.53 a$ & $0.43 b$ & $18.3^{\# \# / a}$ & $12.9^{\# \# / \mathrm{b}}$ & $6.6^{\# \# / a}$ & $5.2^{\# \# / \mathrm{b}}$ & $24.7^{\# \# / a}$ & $18.2 / \mathrm{b}$ \\
\hline & $(0.11)$ & $(0.08)$ & (12.6) & $(9.5)$ & $(3.4)$ & $(2.5)$ & $(14.8)$ & (10.9) \\
\hline \multirow[t]{2}{*}{ After harvest } & $0.53 \mathrm{a}$ & $0.45 b$ & $8.5^{\# / a}$ & $2.7^{\#} / \mathrm{b}$ & $2.8^{\# / a}$ & $1.5^{\mathrm{H}} \mathrm{b}$ & $11.4^{\# / a}$ & $4.3^{\# / b}$ \\
\hline & $(0.09)$ & $(0.05)$ & $(6.2)$ & (2.6) & (1.7) & (0.7) & (7.3) & (3.0) \\
\hline
\end{tabular}

In brackets: standard deviation. Different number of symbols ${ }^{\#}$ ) show significant differences between before and after the harvest; Different letters show significant differences between inside and outside the cylinders. Mean were calculated for 67 months before harvest and for 23 months after harvest $(\alpha=0.05)$.

Net ammonification $=$ gross mineralization - microbial $\mathrm{NH}_{4}^{+}-\mathrm{N}$ immobilization - fixation on silicate clays - gross nitrification $=$ $\mathrm{T}_{1 \mathrm{NH} 4}-\mathrm{T}_{0 \mathrm{NH} 4}-$ external inputs of $\mathrm{NH}_{4}+$ leaching of $\mathrm{NH}_{4}$ inside the cylinders ${ }^{1}$.

Net mineralisation $=$ net nitrification + net ammonification .

Root uptake $=\mathrm{T}_{1}-\mathrm{T}_{0 \mathrm{f}}-$ leaching outside the cylinders + leaching inside the cylinders.

It was not necessary to quantify microbial immobilisation because it was assumed to be similar inside and outside the cylinders (this point will be discussed later).

\subsection{Statistical analysis}

Each year, the annual fluxes were calculated by adding up the 13 4-week incubation period fluxes. As in 1993 only summer month data are available, we calculated the before-harvest annual mean by the sum of the summer mean (from 1993 to 1998) and the winter mean (from 1994 to 1998). Statistical analysis was carried out using StatView 512 software [1]. Differences between contents (moisture, nitrate-N, ammonium-N, mineral $\mathrm{N}$ ) or fluxes (inputs, leaching, nitrification, ammonification, mineralisation) before and after harvest were tested with analysis of variance (ANOVA) and a t-test was carried out on successive measurements of four-week incubation periods. Differences between contents and fluxes measured inside and outside the cylinders were tested with a t-test on the differences of paired values. Correlations between data were tested using the Pearson's test. All differences were assumed to be significant at 5\% risk level.

\section{RESULTS}

\subsection{N requirement of above-ground biomass}

The annual $\mathrm{N}$ requirement for the different above-ground components of vegetation was $38 \mathrm{~kg} \mathrm{~N} \cdot \mathrm{ha}^{-1} \cdot \mathrm{yr}^{-1}$ for needles, $27 \mathrm{~kg} \mathrm{~N} \cdot \mathrm{ha}^{-1} \cdot \mathrm{yr}^{-1}$ for branches and twigs and $7 \mathrm{~kg} \mathrm{~N} \cdot \mathrm{ha}^{-1} \cdot \mathrm{yr}^{-1}$ for bole and bark, from which $26 \mathrm{~kg}$ originated from internal trans- locations into the tree [53]. Above-ground understorey biomass was $2.8 \mathrm{t} \cdot \mathrm{ha}^{-1}$ before the harvest and contained $43 \mathrm{~kg} \mathrm{~N} \cdot \mathrm{ha}^{-1}$. As the understorey was composed mainly of biennial species, a mean $\mathrm{N}$ annual requirement of $21.5 \mathrm{~kg} \mathrm{~N} \cdot \mathrm{ha}^{-1}$ for aerial understorey biomass was assumed.

One year after the harvest, above-ground understorey biomass was $4.8 \mathrm{t} \cdot \mathrm{ha}^{-1}$ and contained $64 \mathrm{~kg} \mathrm{~N} \cdot \mathrm{ha}^{-1}$, which implied an annual requirement of $42.5 \mathrm{~kg} \mathrm{~N} \cdot \mathrm{ha}^{-1}$ using the same hypothesis.

No data were available for the below-ground parts of vegetation in this stand. Root biomass and nutrient content was measured in the 47-year-old stand of the chronosequence and was estimated to represent $20 \%$ of the aerial biomass and $15 \%$ of its $\mathrm{N}$ content [66].

\subsection{Soil physical and chemical conditions}

After clear-cutting, the mean annual air temperature did not significantly increase. The mean annual temperature in the soil increased at the different levels registered (Tab. II), especially during summer. Daily temperature variations also increased strongly after felling (data not shown).

The mean water content of the undisturbed soil was not significantly different before and after the harvest $\left(0.43 \mathrm{~g} \cdot \mathrm{g}^{-1}\right.$ for 67 months vs. $0.45 \mathrm{~g} \cdot \mathrm{g}^{-1}$ for 23 months, Tab. III). The mean water content of the incubated soil was identical before and after the harvest $\left(0.53 \mathrm{~g} \cdot \mathrm{g}^{-1}\right)$. Mean water contents were greater in the incubated soils than in the undisturbed soils, before and after the harvest.

Before the harvest, nitrate was the dominant form of mineral $\mathrm{N}$ in the incubated $(75 \%)$ and undisturbed soil (71\%, Tab. III, Fig. 1). After the harvest, nitrate was still the main form of mineral $\mathrm{N}$ but had decreased to $63 \%$ in the undisturbed soils. All $\mathrm{N}$ concentrations $\left(\mathrm{mg} \cdot \mathrm{kg}^{-1}\right)$ were significantly higher inside 
Table IV. Mineral nitrogen deposited on the soil, canopy uptake, net nitrification, net ammonification and net mineralisation of $\mathrm{N}(0-15 \mathrm{~cm})$ before and after harvest (all data in $\mathrm{kg} \mathrm{N} \cdot \mathrm{ha}^{-1} \cdot \mathrm{yr}^{-1}$ ).

\begin{tabular}{|c|c|c|c|c|c|c|c|c|}
\hline & $\begin{array}{l}\text { Bulk precipitation } \\
\text { (1) }\end{array}$ & $\begin{array}{c}\text { Dry deposition } \\
\text { (2) }\end{array}$ & $\begin{array}{l}\text { Total deposition } \\
\quad(3=1+2)\end{array}$ & $\begin{array}{c}\text { Throughfall } \\
\text { (4) }\end{array}$ & $\begin{array}{c}\text { Canopy uptake } \\
(5=3-4)\end{array}$ & $\begin{array}{l}\text { Nitrification } \\
\text { (6) }\end{array}$ & $\begin{array}{c}\text { Ammonification } \\
\text { (7) }\end{array}$ & $\begin{array}{c}\text { Mineralisation } \\
(6+7)\end{array}$ \\
\hline \multirow[t]{2}{*}{ Before } & $8.4^{\#}$ & 12.4 & $20.8^{\# \#}$ & 19.0 & 1.8 & $191^{\# \# / a}$ & $35^{\# \# / \mathrm{b}}$ & $226^{\# \mathrm{v}}$ \\
\hline & $(0.4)$ & (3.8) & (4.1) & (13.9) & & (144) & (55) & (175) \\
\hline \multirow[t]{2}{*}{ After } & $9.3^{\#}$ & - & $9.3^{\#}$ & - & - & $148^{\# / a}$ & $19^{\# / \mathrm{b}}$ & $167^{\#}$ \\
\hline & $(0.5)$ & & $(0.5)$ & & & (80) & (25) & (95) \\
\hline
\end{tabular}

In brackets: standard deviation of 4-week periods reported to an annual basis; Different number of symbols (\#) show significant differences before and after the harvest; Different letters show significant differences between nitrification and ammonification $(\alpha=0.05)$.

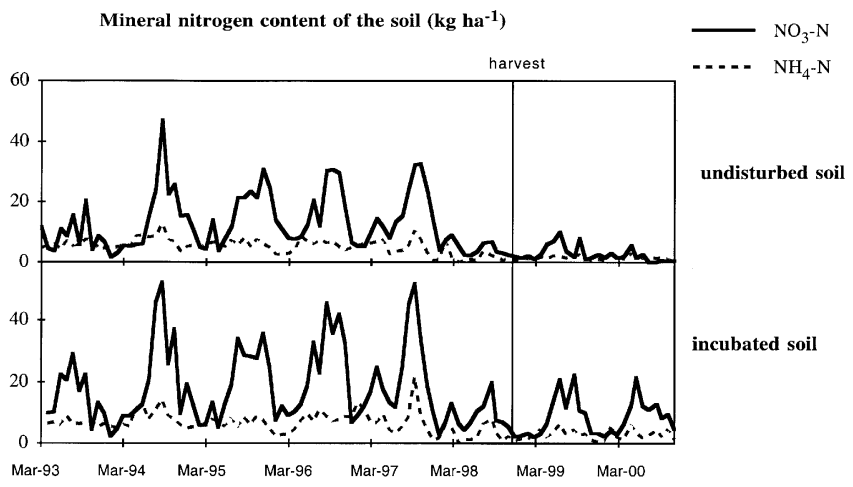

Figure 1. Evolution of mineral nitrogen contents of the undisturbed and incubated soil.

than outside the cylinders before and after harvest, and were significantly lower after harvest. However, a significant decrease was registered the last year before harvest: in 1998 (November 1997-November 1998) mean $\mathrm{NO}_{3}-\mathrm{N}$ and $\mathrm{NH}_{4}-\mathrm{N}$ contents were lower than for the previous years (Fig. 1). Nitrate-N and mineral-N contents did not vary significantly between years before the harvest [41], except in 1998, or after the harvest, but all $\mathrm{N}$ contents were significantly greater during "summer" (from mid-April to mid-October) than during "winter" (from mid-October to mid-April) and fluctuated considerably according to an annual cycle (Fig. 1). The mineral-N contents inside and outside cylinders were significantly correlated before harvest $\left(\mathrm{y}=1.22 \mathrm{x}+2.85, r^{2}=0.83, n=72, P<0.05\right)$. After harvest, the two contents were still correlated, but the correlation coefficient value decreased $\left(\mathrm{y}=1.13 \mathrm{x}+6.59, r^{2}=0.21, n=26\right.$, $P<0.05)$.

There were only a few other significant changes in the soil biochemical status: the organic carbon content of the forest floor decreased from 16.6 to $8.3 \mathrm{t} \cdot \mathrm{ha}^{-1}$ between September 1998 and September 2000, and increased by $6.7,4.0$ and $1.9 \mathrm{t} \cdot \mathrm{ha}^{-1}$ respectively in the $0-5 \times, 5-10$ and $10-15 \mathrm{~cm}$ layers $(P<0.05)$. During the same period, the forest floor lost $323 \mathrm{~kg} \cdot \mathrm{ha}^{-1}$, but a significant increase of $430 \mathrm{~kg} \cdot \mathrm{ha}^{-1}$ was observed for total soil organic- $\mathrm{N}$ in the $[0-5 \mathrm{~cm}]$ and $[5-10 \mathrm{~cm}]$ layer, coming from the transfer of the forest floor and turnover of the root system.

\section{3. $N$ deposition to soil}

Before the harvest, nitrate was the main form of $\mathrm{N}$ deposited on the top soil by throughfall (60\% of $\mathrm{N}$ deposition). Dry depo-

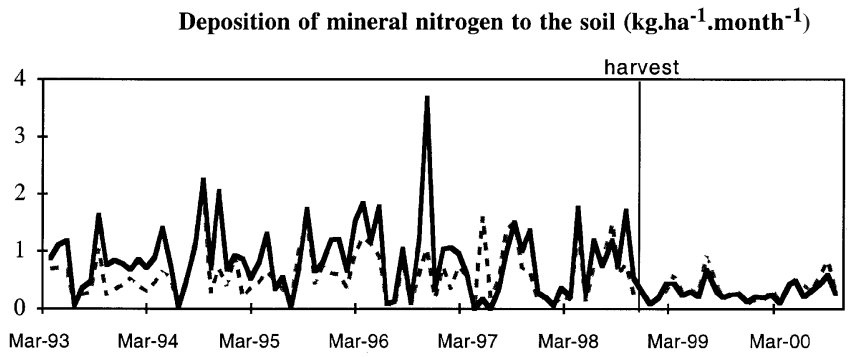

Figure 2. Deposition of mineral nitrogen to the soil in $\mathrm{kg} \cdot \mathrm{ha}^{-1} \cdot \mathrm{month}^{-1}$.

sition before harvest was $12.4 \mathrm{~kg} \mathrm{~N} \cdot \mathrm{ha}^{-1} \cdot \mathrm{yr}^{-1}$ [70] indicating an almost negligible $\mathrm{N}$ uptake by the canopy $\left(1.8 \mathrm{~kg} \mathrm{~N} \cdot \mathrm{ha}^{-1} \cdot \mathrm{yr}^{-1}\right)$ in this mature stand. After the harvest, $\mathrm{N}$ deposition to the soil was only due to bulk precipitation, and $\mathrm{NH}_{4}-\mathrm{N}$ was significantly higher than $\mathrm{NO}_{3}-\mathrm{N}$ deposition $(54 \%$ of total $\mathrm{N}$ deposition). All inputs to soil significantly decreased after harvest (Tab. IV and Fig. 2) but the mean annual $\mathrm{N}$ amount in bulk precipitation remained nearly unchanged (Tab. IV). There was no significant difference between seasons for $\mathrm{NO}_{3}-\mathrm{N}$ deposition, but $\mathrm{NH}_{4}-\mathrm{N}$ deposition was greater in "summer" than in "winter" before and after harvest.

\subsection{Production fluxes and root uptake of soil mineral $\mathbf{N}$}

Annual net mineralisation before the harvest varied from $175 \mathrm{~kg} \mathrm{~N} \cdot \mathrm{ha}^{-1} \cdot \mathrm{yr}^{-1}$ in 1995 to $267 \mathrm{~kg} \mathrm{~N} \cdot \mathrm{ha}^{-1} \cdot \mathrm{yr}^{-1}$ in 1997, with a mean annual value of $225 \mathrm{~kg} \mathrm{~N} \cdot \mathrm{ha}^{-\mathrm{yr}^{-1}}$ (Tab. IV). Roughly $85 \%$ of the mineralised $N$ was nitrified. Net mineralisation and net nitrification of N were greater in "summer" than in "winter" (Figs. 3a and 3b). The inter-annual variation of the fluxes was high, but net mineralisation and net nitrification were significantly lower after harvest.

Annual net $\mathrm{N}$ uptake by roots (calculated by differences in leaching, see equations) varied from $125 \mathrm{~kg} \cdot \mathrm{ha}^{-1} \cdot \mathrm{yr}^{-1}$ in 1995 to $244 \mathrm{~kg} \cdot \mathrm{ha}^{-1} \cdot \mathrm{yr}^{-1}$ in 1997 before the harvest and was greater during "summer" (70\% of the annual uptake on average) than during "winter" (Fig. 3c). The annual mean uptake was lower after the harvest (162 kg N.ha ${ }^{-1}$ vs. 187 before), but the decrease was not significant (Tab. V), and the uptake still showed the same seasonal trend. Annual $\mathrm{N}$ mineralisation exceeded annual root uptake by $40 \mathrm{~kg} \cdot \mathrm{ha}^{-1}$ before the harvest but the two fluxes were roughly equal after the harvest. 


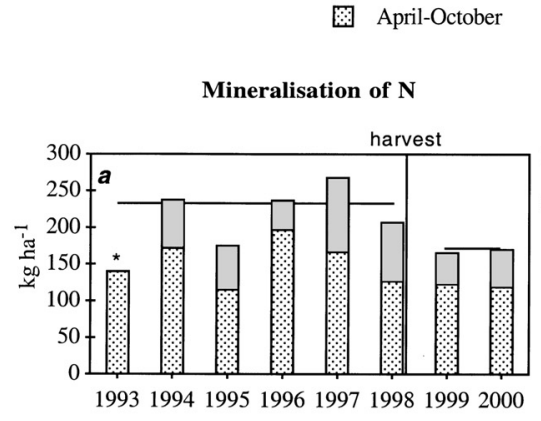

October-April
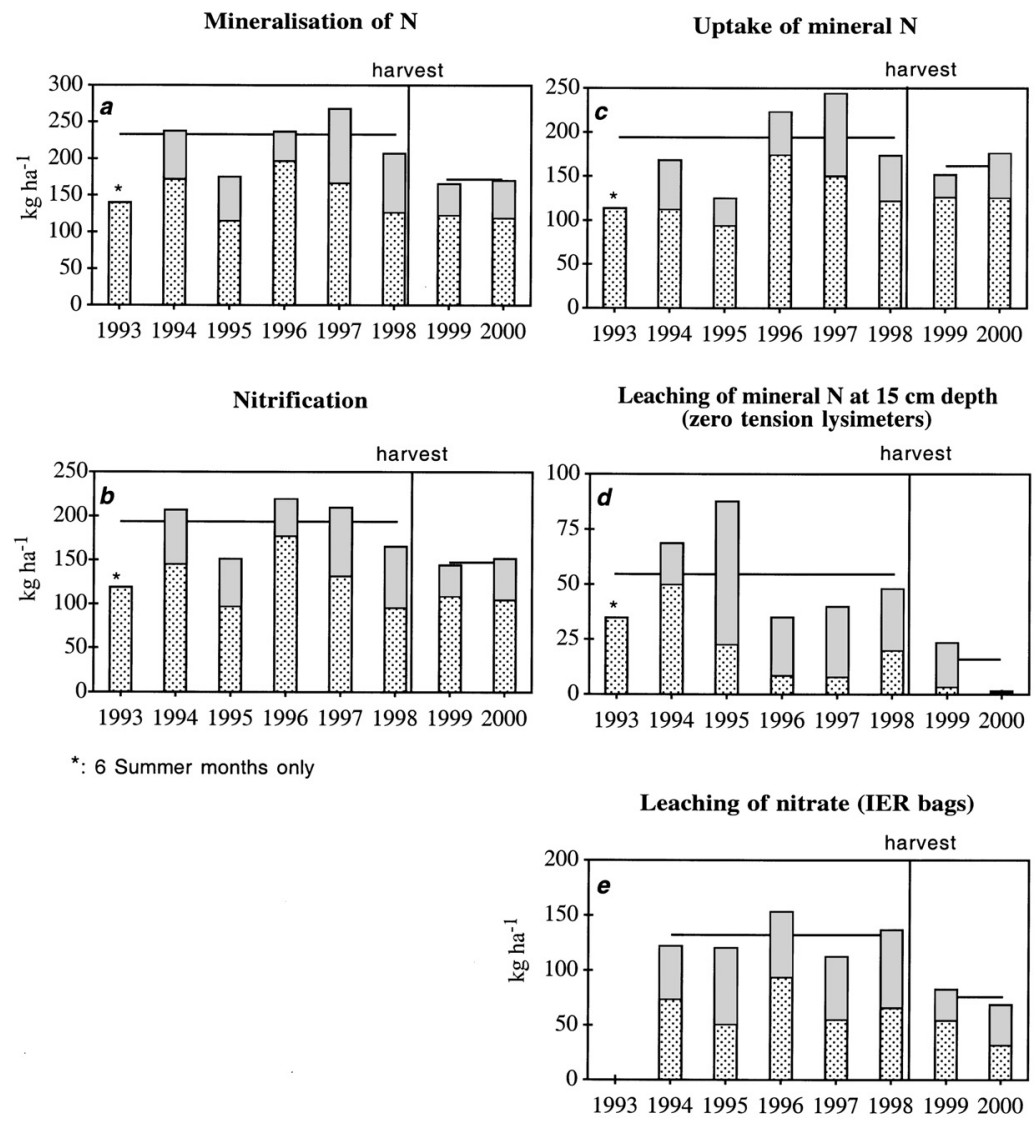

Figure 3. Annual mean of fluxes before and after the harvest, according to the season; (a) Net mineralisation of nitrogen; (b) Net nitrification; (c) Uptake of mineral N; (d) Leaching of mineral $\mathrm{N}$ from undisturbed soil at $15 \mathrm{~cm}$ depth; (e) Leaching of nitrate-N from incubated soil. The lines show the sum of mean "winter" and "summer" fluxes.

\subsection{Leaching of nitrogen and nutrients through the soil}

Nitrate was the main form of mineral $\mathrm{N}$ leached before the harvest (Tab. V): $96 \%$ of mineral $\mathrm{N}$ leached in zero tension lysimeters and $84 \%$ in IER bags (soil without root uptake in the cylinders). Leaching of ammonium at $15 \mathrm{~cm}$ depth in the undisturbed soil was very small. Leaching of ammonium (from incubated and undisturbed soil) was greater during "summer" than during winter (data not shown). $\mathrm{N}$ leaching from the soil cores (incubated soil) was much higher than outside (Tab. V): N leaching increased by $100 \mathrm{~kg} \cdot \mathrm{ha}^{-1} \cdot \mathrm{yr}^{-1}$ when roots were cut. There were significant correlations between $\mathrm{NO}_{3}-\mathrm{N}$ (or $\mathrm{NH}_{4}-\mathrm{N}$ ) leached from the soil with and without roots (data not shown). Before the harvest, leaching of nitrogen decreased to about $6 \mathrm{~kg} \cdot \mathrm{ha}^{-1} \cdot \mathrm{yr}^{-1}$ at $60 \mathrm{~cm}$ depth, and was $33 \mathrm{~kg} \mathrm{~N} \cdot \mathrm{ha}^{-1} \cdot \mathrm{yr}^{-1}$ at $120 \mathrm{~cm}$ depth [53]. Leaching of $\mathrm{Ca}, \mathrm{K}$ and $\mathrm{Mg}$ was high at $15 \mathrm{~cm}$ depth $\left(47,23\right.$ and $8 \mathrm{~kg} \cdot \mathrm{ha}^{-1} \cdot \mathrm{yr}^{-1}$ respectively), decreased at $60 \mathrm{~cm}$ depth $\left(5,5\right.$ and $2 \mathrm{~kg} \cdot \mathrm{ha}^{-1} \cdot \mathrm{yr}^{-1}$ respectively), and intermediate at $120 \mathrm{~cm}$ depth $\left(9,15\right.$ and $5 \mathrm{~kg} \cdot \mathrm{ha}^{-1} \cdot \mathrm{yr}^{-1}$ respectively $)$.

Leaching of total mineral $\mathrm{N}$ at $15 \mathrm{~cm}$ depth significantly decreased after the harvest (Tab. V, Figs. 3d and 3e), from 56 to $26 \mathrm{~kg} \mathrm{~N} \cdot \mathrm{ha}^{-1}$ in the undisturbed soil the first year after clearcutting and to $2 \mathrm{~kg} \mathrm{~N} \cdot \mathrm{ha}^{-1}$ the second year, and from 153 to $80 \mathrm{~kg} \mathrm{~N} \cdot \mathrm{ha}^{-1} \cdot \mathrm{yr}^{-1}$ in the incubated soil. Nitrate was still the main form of mineral $\mathrm{N}$ leached from the soil, with and without root uptake (91 and $92 \%$ respectively, Tab. V). Leaching of ammo- nium was higher during the "summer" period, and nitrate leaching (and total mineral $\mathrm{N}$ ) was significantly higher during the "winter" period. Leaching of $\mathrm{N}$ was still $60 \mathrm{~kg} \cdot \mathrm{ha}^{-1} \cdot \mathrm{yr}^{-1}$ higher in the cylinders. The relationships between leaching of $\mathrm{NO}_{3}-\mathrm{N}$ (or $\mathrm{NH}_{4}-\mathrm{N}$ ) in the undisturbed and the incubated soil were no longer significant (not shown).

Quantitative budgets were established after the harvest for $\mathrm{Ca}, \mathrm{Mg}$ and $\mathrm{N}$ below $15 \mathrm{~cm}$ depth. Fluxes of $\mathrm{Ca}$ and $\mathrm{Mg}$ at $60 \mathrm{~cm}$ depth were unchanged, 6 and $6.8 \mathrm{~kg} \cdot \mathrm{ha}^{-1} \cdot \mathrm{yr}^{-1}$ before and after harvest respectively for $\mathrm{Ca}, 2.2$ and $2.5 \mathrm{~kg} \cdot \mathrm{ha}^{-1} \cdot \mathrm{yr}^{-1}$ before and after harvest respectively for $\mathrm{Mg}$. Nitrogen fluxes $\left(\mathrm{NO}_{3}-\mathrm{N}+\right.$ $\mathrm{NH}_{4}-\mathrm{N}$ ) increased from 6.5 to $13.7 \mathrm{~kg} \cdot \mathrm{ha}^{-1} \cdot \mathrm{yr}^{-1}$ at $60 \mathrm{~cm}$ depth. At $120 \mathrm{~cm}$ depth, fluxes were strongly depleted, from 25 to $7.2 \mathrm{~kg} \cdot \mathrm{ha}^{-1} \cdot \mathrm{yr}^{-1}$ for $\mathrm{N}$, from 14 to $9.6 \mathrm{~kg} \cdot \mathrm{ha}^{-1} \cdot \mathrm{yr}^{-1}$ for $\mathrm{Ca}$, from 3.9 to $2.4 \mathrm{~kg} \cdot \mathrm{ha}^{-1} \cdot \mathrm{yr}^{-1}$ for $\mathrm{Mg}$.

\subsection{Nitrogen fluxes before and after clear-felling}

Changes in fluxes of mineral nitrogen are represented in Figure 4. Before the harvest, the main source of mineral $\mathrm{N}$ for the soil was the mineralisation $\left(225 \mathrm{~kg} \mathrm{~N} \cdot \mathrm{ha}^{-1} \cdot \mathrm{yr}^{-1}\right)$. Inputs to the soil via throughfall reached $19.5 \mathrm{~kg} \mathrm{~N} \cdot \mathrm{ha}^{-1} \cdot \mathrm{yr}^{-1}$. The mean annual amount of available mineral $\mathrm{N}$ in the soil reached $244.5 \mathrm{~kg} \mathrm{~N} \cdot \mathrm{ha}^{-1} \cdot \mathrm{yr}^{-1}$. From these $244.5 \mathrm{~kg} \mathrm{~N}, 46$ were taken up by the tree roots, 22 by the understorey aboveground biomass and 56 were leached. $119 \mathrm{~kg} \mathrm{~N}$ were used by fine root (both tree and understorey) turnover, mycorrhizae, and a part may 
Table V. Annual uptake of mineral $\mathrm{N}$ by roots and mineral nitrogen leaching at $15 \mathrm{~cm}$ depth (all data in $\mathrm{kg} \mathrm{N} \cdot \mathrm{ha}^{-1} \cdot \mathrm{yr}^{-1}$ ).

\begin{tabular}{|c|c|c|c|c|c|}
\hline & \multirow[t]{3}{*}{ Uptake of $\mathrm{N}$} & \multicolumn{4}{|c|}{ Nitrogen leaching at $15 \mathrm{~cm}$ depth } \\
\hline & & \multicolumn{2}{|c|}{ Zero-tension lysimeters } & \multicolumn{2}{|c|}{ IER bags } \\
\hline & & $\mathrm{NO}_{3}^{-}-\mathrm{N}$ & $\mathrm{NH}_{4}^{+}-\mathrm{N}$ & $\mathrm{NO}_{3}^{-}-\mathrm{N}$ & $\mathrm{NH}_{4}^{+}-\mathrm{N}$ \\
\hline Before the harvest & 187 & $54^{\# \# / \mathrm{a}}$ & $2.1^{\# \# / \mathrm{b}}$ & $128^{\# \# / a}$ & $25^{\# \# / \mathrm{b}}$ \\
\hline (standard deviation) & (139) & (84) & (2.9) & $(81)$ & (46) \\
\hline After the harvest & 162 & $13^{\# / a}$ & $1.0^{\# / \mathrm{b}}$ & $74^{\# / a}$ & $6^{\# / \mathrm{b}}$ \\
\hline (standard deviation) & (106) & (29) & (1.8) & $(42)$ & (6) \\
\hline
\end{tabular}

Standard deviations were calculated over four week periods and reported to an annual basis; Different number of asterisks show significant differences before and after the harvest; Different letters show significant diffrences between leaching of $\mathrm{NO}_{3}^{-}-\mathrm{N}$ and $\mathrm{NH}_{4}-\mathrm{N}$.

have been lost by denitrification. Two years after the harvest, nitrogen availability in the upper soil surface strongly decreased, due to a strong decrease in mineralisation, from 245 to $167 \mathrm{~kg} \cdot \mathrm{ha}^{-1}$. Uptake by the understorey aboveground biomass was higher (42.5 kg.ha-1 vs. 22), but lower than the preharvest whole vegetation uptake. Leaching of nitrogen at $15 \mathrm{~cm}$ depth strongly decreased (from 56 to $14 \mathrm{~kg} \cdot \mathrm{ha}^{-1} \cdot \mathrm{yr}^{-1}$ ), meaning a fine-root and fungi requirement still equal to $119 \mathrm{~kg} \mathrm{~N} \cdot \mathrm{ha}^{-1} \cdot \mathrm{yr}^{-1}$.

\section{DISCUSSION}

\subsection{Limits of the in situ incubation method}

Numerous studies discuss the possible bias of the in situ incubation method (see for instance Raison et al. [65], Adams et al. [2], Sierra [73], Jussy et al. [41]). The method is based on the assumptions that physical and chemical conditions are similar inside and outside the cylinders and that the production rate of mineral $\mathrm{N}$ is not modified inside the cylinders.

Soil compaction within the cylinders was limited by the use of cylinders with a $7.6 \mathrm{~cm}$ inner diameter. A four-week period was chosen between two sampling dates. It was assumed to be short enough to reduce the differences in physical conditions and long enough to observe differences in $\mathrm{N}$ concentrations inside and outside the cylinders [65] and to produce substantial $\mathrm{N}$ amounts in the solution collectors.

However, the very high uptake of $\mathrm{N}$ calculated even after the harvest, raises questions about the validity of the results. The difference after the harvest between calculated uptake of $\mathrm{N}$ (162 $\mathrm{kg} \cdot \mathrm{ha}^{-1} \cdot \mathrm{yr}^{-1}$, see Sect. 3.4) and the requirements of understorey vegetation for above-ground biomass (42.5 kg N.ha ${ }^{-1} \cdot \mathrm{yr}^{-1}$, see Sect. 3.1) cannot easily be explained, even with a root requirement two-fold higher than the above-ground requirement. Sources of overestimation need to be investigated. Although leaching was allowed at the bottom of the cylinders, soil moisture was higher inside the cylinders (Tab. III) due to suppression of water uptake by roots. This higher soil moisture may have led to overestimating production and uptake rates [29]. However, Sierra [73] did not find a high response of mineralisation to an increase in soil moisture inside incubated cylinders of soil, and nor did Jussy [40] find such a response in laboratory incubations of this specific soil. Other explanations may be linked to the extra mineralisation of severed roots within the cylin- ders [33] which would also lead to overestimating $\mathrm{T}_{1}$. Living roots may also have an inhibiting effect on mineralisation, which would be suppressed in the cylinders, causing an "artificial" increase in $\mathrm{T}_{1}$, as monoterpenes produced by living roots probably have an inhibiting effect on nitrification [60].

On the other hand, severed roots still might act as sinks of $\mathrm{N}$ as long as roots are living [65]. The lifespan of Douglas-fir roots after felling is not documented. Microbial immobilisation might be favoured by fresh organic matter (severed roots) and higher soil moisture in the cylinders. Consequently, production and uptake rates would be underestimated.

Unfortunately, none of these processes have yet been quantified but although each may possibly occur, the result is probably an overestimation of the nitrogen content inside the cylinders.

Other fluxes were not measured. Denitrification fluxes, which led to underestimated nitrification rates (see equations), might not be high in such a silty well-drained soil [44, 52]. As temperature increased after harvest and soil moisture was high inside the cylinders, denitrification may have increased and may have led to the apparent decrease in net nitrification [18, 45]. Dry deposition after the harvest was not calculated, and was supposed to be lower than before as interception by canopy was considerably reduced. Taking it into account would have slightly reduced the amount of $\mathrm{N}$ mineralised (up to $12 \mathrm{~kg} \mathrm{~N} \cdot \mathrm{ha}^{-1} \cdot \mathrm{yr}^{-1}$ ).

The absolute values of the calculated fluxes are subject to the above-mentioned potential bias, the high spatial variability of $\mathrm{N}$ concentrations in soil, and the use of empirical relationships to correct for extraction procedures. Moreover, only the upper layer was taken into account and we previously found that potential production in the $0-15 \mathrm{~cm}$ layer reached only $65 \%$ of the total soil production in an adjacent Douglas-fir stand [42]. Changes following clear-felling will be discussed more fully than absolute values of fluxes.

\subsection{The $N$ cycle before the harvest}

$\mathrm{N}$ deposition to the soil via throughfall was within the range of European data [30] but was rather high in comparison to a set of French data [83].

Mean annual litterfall in the mature Douglas-fir stand was estimated at $1.7 \mathrm{t} \cdot \mathrm{ha}^{-1} \cdot \mathrm{yr}^{-1}$ of $\mathrm{C}$ and $32 \mathrm{~kg} \cdot \mathrm{ha}^{-1} \cdot \mathrm{yr}^{-1}$ of $\mathrm{N}$ [71].

Mineralisation and nitrification were especially high, even taking into account possible methodological bias. The acidity 


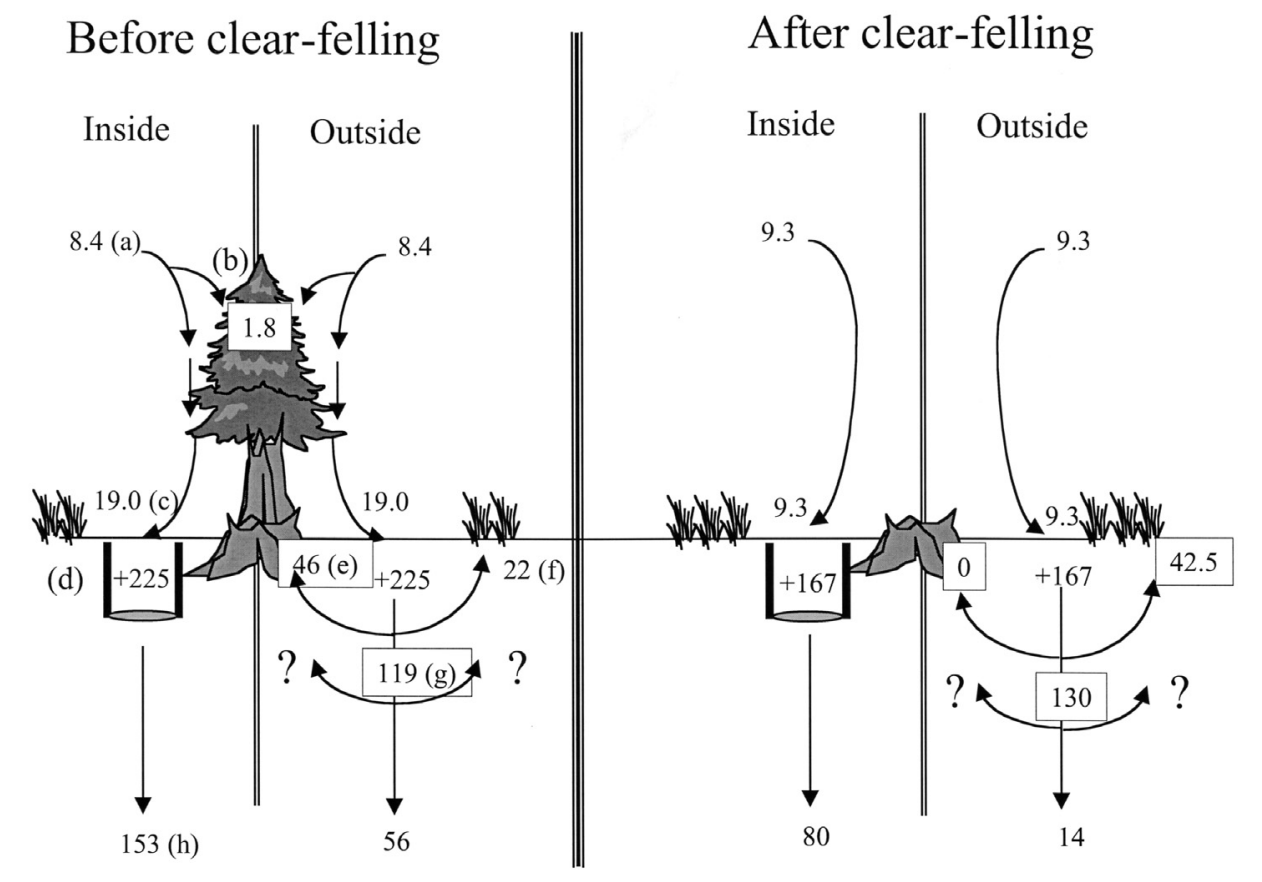

\section{After clear-felling}

Figure 4. Fluxes of mineral nitrogen before and after the harvest (in $\mathrm{kg} \mathrm{N} \cdot \mathrm{ha}^{-1} \cdot \mathrm{yr}^{-1}$ ) inside and outside the cylinders. (a) Rainfall; (b) uptake by canopy; (c) deposition to the soil; (d) mineralisation; (e) uptake by above-ground tree biomass; (f) requirement of above-ground understorey biomass; (g) calculated root requirement; (h) leaching.

of the soil had no inhibiting effect on the nitrifying capacity, as previously found in many other studies [19,39,62,81]. Marques [53] hypothesised that the change in vegetation via the introduction of Douglas-fir has led to the destabilisation of the organic matter. Moreover, high net nitrification rates [16, 42] or mineralisation rates $[3,52]$ were also measured in forests planted on formerly cultivated sites. Increased mineralisation has probably been triggered by deforestation, tillage [48] and accumulation of a labile pool of organic matter during the cultivation period, and may have persisted because of practices improving soil fertility and microbial population dynamics (manuring). Long-lasting effects of land cultivation were demonstrated on soil N-dynamics [43]. Results obtained recently on another Douglas-fir stand in the experimental site of Breuil (Morvan, France) lead to hypothesise that Douglas-fir could develop a specific control on soil-nitrifiers. In the Morvan experimental site, different species planted in strictly identical conditions showed very different patterns of residual nitrates in soil solutions, rate of nitrification in laboratory incubations, and structure of microbial populations. Once again Douglas-fir soil had one of the highest nitrifying capacities (Ranger coordinator, work in progress, unpublished data). Uptake of $\mathrm{N}$ by roots was high but was lower than mineralisation. Mineralisation and root uptake were generally lower during the "winter" season, but the dormant season is probably shorter than 5 months, and a part of the calculated fluxes might originate from the extended microflora activity. Canopy uptake before the harvest was low and almost negligible.

The annual $\mathrm{N}$ requirement and uptake from the soil nutrient reserves for above-ground biomass increment (stand and understorey) was very much lower than the calculated uptake of nitrogen. The major uncertainty concerns the $\mathrm{N}$ pool alloca- ted to fine roots, for which no data were available. Ranger and Gelhaye [66] in a 47-year-old adjacent Douglas-fir stand, found a $\mathrm{N}$ content in fine roots of $7.7 \mathrm{~kg} \mathrm{~N} \cdot \mathrm{ha}^{-1}$, which was probably underestimated by the sampling method. In the study stand, since $\mathrm{N}$ content in aboveground biomass was higher (700 vs. $540 \mathrm{~kg} \mathrm{~N} \cdot \mathrm{ha}^{-1}$ [53]), fine root $\mathrm{N}$ content could have reached $11 \mathrm{~kg} \cdot \mathrm{ha}^{-1}$, considering below-ground biomass to be roughly $20 \%$ of the aboveground biomass [66]. However, the root turnover rate was unknown. It has previously been calculated that fine-root litter production including mycorrhizae could reach 2.3 to 2.5 fold the yearly $\mathrm{N}$ in needle litterfall value $[76,38]$. In the present study, this would imply a root litter production containing 87 to $95 \mathrm{~kg} \mathrm{~N} \cdot \mathrm{ha}^{-1} \cdot \mathrm{yr}^{-1}$. Such an annual allocation to fine roots is probably excessive and may only be explained by a rapid turnover of the total fine root biomass, and/or by the overestimation of fluxes. It implies at least that the root system still lives after cutting. In North America and Europe, calculated fine root turnover of various mature stands varies from two months to more than two years $[58,77]$.

Leaching of $\mathrm{N}$ at $15 \mathrm{~cm}$, essentially nitrate, was higher than $\mathrm{N}$ deposition, contrary to the results of Gundersen et al. [31]. The sink function of vegetation (stand and understorey) was not sufficient to impede leaching, as net mineralisation exceeded $\mathrm{N}$ uptake. Nitrate leaching has already been observed in forest soils previously cultivated $[25,52]$ or grazed by pigs [59]. At the profile level, this $\mathrm{N}$ leaching was still high at $120 \mathrm{~cm}$ depth [56]. Losses increased further when roots were cut. This N leaching contributed to soil acidification. It was accompanied by a leaching of $\mathrm{Ca}$ and $\mathrm{Mg}$ higher than $\mathrm{Ca}$ and $\mathrm{Mg}$ in atmospheric deposits and may lead to a decrease in soil fertility [53]. At this site, $\mathrm{N}$ leaching was partly controlled by root activity and partly by nitrification. 


\subsection{Consequences of the harvest}

\subsubsection{Physical and chemical conditions of the soil}

Numerous authors have described changes in the physical and chemical status of forest soils after a clear-cut as an increase in soil moisture [26], increase in pH and in BS [63]. For McColl [50], soil moisture is enhanced after a clear-cut due to the decrease in evapotranspiration. On the other hand, a decrease in water content of the litter due to an increase in temperature of the barren soil has also been measured [17,34]. At the study site, where the air temperature was found to be unchanged, soil temperature increased, except during the winter months due to the suppression of canopy interaction [35]. As residues and needles were left on the soil and manually stacked, as the forest floor was not greatly disturbed, and as the ground vegetation was not controlled, heating of the soil and evapotranspiration might have been limited, and soil moisture increase was limited. The soil chemical status of the stand underwent limited but significant changes after the clear-cut: (i) increase in organic carbon content on the soil surface which, combined with the organic $\mathrm{N}$ decrease, led to a small increase in $\mathrm{C}: \mathrm{N}$ ratio of organic matter in the $\mathrm{A}_{1}$ layer and (ii) increase in the "base" cations that could be explained by the intense mineralisation of the forest-floor. However, as noted previously [61], two years is too short a duration to establish any long-term effect of clearcutting on soil fertility. On the other hand, Vitousek et al. [90] found that when understorey vegetation and young stand were covering the soil, major changes were unlikely to occur 2 years after harvest.

\subsection{2. $N$ inputs to the soil}

Atmospheric $\mathrm{N}$ deposition to the soil significantly decreased after the harvest, but the amount of $\mathrm{N}$ in bulk deposition was not significantly modified by the clear cut $\left(8.4 \mathrm{~kg} \mathrm{~N} \cdot \mathrm{ha}^{-1} \cdot \mathrm{yr}^{-1}\right.$ on average before and $9.3 \mathrm{~kg} \mathrm{~N} \cdot \mathrm{ha}^{-1} \cdot \mathrm{yr}^{-1}$ after the harvest). The change could be explained by the suppression of the canopy which favoured the dry deposition of $\mathrm{N}$ due to the filtering capacity of the canopy of the mature stand [7]. As dry deposition was not quantified on ground vegetation after the harvest, the difference was probably smaller than calculated.

The break in litterfall returns after clear-cut led to a large disruption in the carbon and nitrogen cycles. The fresh material from litterfall provided the soil with labile organic components easily used by the micro-organisms, which disappeared after stand cutting.

\subsubsection{Nitrogen availability}

All parameters of nitrogen availability, i.e. nitrogen contents in the soil and mineralisation (or nitrification) rate decreased significantly after the harvest, demonstrating that soil moisture and temperature did not play a major role in net nitrogen mineralisation or net nitrification. It should also be noted that nitrification and mineralisation fluxes in 1995 were not different from those measured in 1999 and 2000 after the harvest, illustrating the high temporal variability of such processes; the lateral variability at the sub-(plot) scale also probably also contributed to this pattern. However, the results are different from those generally found in the literature. According to Harvey et al. [32], the decomposition rate of organic matter and consequently the nitrogen mineralisation rate increases after a clear-cut.
Several authors have described an increase in nitrogen availability after a clear-cut $[8,78,87]$ and other studies describe an increase in nitrogen mineralisation or nitrification, after a lag time due to microbial immobilisation [86, 89]. Hence, high nitrate contents have been measured four years after the clear-cut in soils showing no nitrification before the harvest [74, 91]. In contrast, Pietikäinen and Fritze [63] measured no increase in nitrification in non-nitrifying soil, although mineralisation increased. Finally, Barg and Edmonds [4] found no change in mineralisation and nitrification rates after partial or total clearcut, as soil moisture, temperature and microbial biomass were constant.

The period of time after the harvest is an important parameter to consider when dealing with the effects of a clear-cut on the nitrogen cycle. Vitousek et al. [90] measured the highest potential mineralisation and nitrification rates and nitrogen availability generally one year after the harvest. In contrast, mineralisable nitrogen might be found lower three years after the harvest than before [13]. In the present study, there were no significant differences in net production fluxes between the two years following the clear-cut, but leaching was significantly lower in 2000 than in 1999, suggesting that nitrogen availability was still decreasing two years after the harvest and that the factors controlling nitrogen leaching was even more efficient.

The type of harvest also plays an important role. In the present study, only stems were harvested. Changes in the nitrogen status were different from those described by Ross et al. [72] who found no change in nitrogen mineralisation or nitrogen in microbial biomass after a stem-only harvest, but measured a decrease in these parameters after a total harvest followed by litter raking, herbicide spraying and reafforestation.

The persisting increase (or decrease) in nitrogen availability has been extensively discussed: long-term effects [15, 88], rapid increase [92] followed by a long term decrease in nitrogen availability by accumulation in residue and humus. For Vitousek et al. [90], the long term effect essentially depends on the influence of the weather on the decomposition rate. Further investigations would have been necessary in this study in order to determine the persistence of the decrease of nitrogen availability or the return to the previous status of the soil.

\subsubsection{Leaching, root decomposition and microbial biomass}

Bormann et al. [9] were amongst the first to demonstrate an increase in nitrate leaching after a clear-cut. The increase generally reached a maximum two to seven years after the harvest, and was followed by a decrease $[11,47,57,85,93]$. In contrast, McColl [51] measured a decrease in nitrogen leaching after a clear-cut, when litter and residues were discarded, whereas an immobilisation of the nutrients in the residues following the harvest was also described $[12,17,26]$. Four factors appear to play important roles: (i) $\mathrm{N}$ status of the soil before the harvest; (ii) treatment applied to the soil (litter raking, ploughing) often involving drastic changes in physical conditions (especially moisture regime) of the soil; (iii) treatment of the remnants (exported, stacked and burned, comminuted, disked...) and (iv) control by understorey vegetation. Some other factors of the ecosystems play a role in the control of nitrogen leaching. As fine roots are very rapidly mineralised, leaching of nitrogen, 
$\mathrm{K}, \mathrm{P}$ and $\mathrm{Mg}$ are generally very high just after a clear-cut, before the growth of new understorey vegetation [24]. On the other hand, after the growth of the understorey, $\mathrm{N}$ leaching is reduced by the uptake of the new vegetation. In the present study, $\mathrm{N}$ content in the above-ground understorey layer increased by $40 \mathrm{~kg} \cdot \mathrm{ha}^{-1}$ after the harvest. The dynamics of $\mathrm{N}$ uptake and growth of biennial species are not well known, so long-term effects of understorey uptake on $\mathrm{N}$ leaching cannot be predicted, as it is possible that the understorey layer has not reached a steady state only two years after the harvest.

Nitrogen leaching also depends on microbial immobilisation, which seems to increase during the first two years after the harvest [22, 49, 79] and may reduce nitrogen leaching. However, Chang et al. [13] concluded that this change does not exceed three years after a new plantation, and Hendrickson et al. [34] and Pietikäinen and Fritze [63] measured a decrease in microbial biomass linked to a decrease in soil moisture. Moreover, Walley et al. [91] observed that microbial biomass had increased four years after a harvest, and found an increase in nitrification rate. At the study site, a limited increase in $\mathrm{N}$ concentration in suction cup lysimeters placed at 15 and $30 \mathrm{~cm}$ depth, but a decrease in the $\mathrm{N}$ concentration in the gravitational solutions, were observed. This suggested that microbial activity was favoured by the forest-floor decomposition and the increase in temperature and moisture, but that microbial immobilisation was enhanced in the soil microporosity [6] and that consequently nitrate availability and nitrate leaching decreased. Hence, measurements of microbial $\mathrm{C}$ after the harvest were two-fold higher than before, indicating a rapid increase in microbial biomass which persists two years after felling, (Andreux and Roux, pers. comm.).

Leaching of other nutrients was limited as concentrations at $120 \mathrm{~cm}$ depth were found unchanged after the harvest. Water leached was probably slightly higher, as interception by tree crowns stopped. Nutrient losses from the ecosystems depend mainly on the output due to harvest (see Ranger et al. [70] for possible values), the increase in microbial immobilisation, and, to an unknown extent, to the change of weathering rate due to the change in net nitrification.

\subsection{Conclusion}

Mineralisation was high before the harvest $\left(225 \mathrm{~kg} \mathrm{~N} \cdot \mathrm{ha}^{-1} \cdot \mathrm{yr}^{-1}\right)$ and nitrification rate was $85 \%$ of the mineralisation in this acidic soil [41]. Atmospheric deposits of $\mathrm{N}$ were relatively high for France. This additional input to a soil with a high rate of nitrification increased the residual nitrates in the soil, and the leaching of both $\mathrm{N}$ and cations [70].

The results showed that even in a situation of very low disturbance of forest soil during felling operations, harvesting resulted in drastic changes in the soil function that could be explained by both the sudden disruption of the biological cycles and by the physical changes in soil climate.

Two years after the harvest, there were significant changes of the soil physical and biochemical conditions. Nitrate was still the main form of mineral nitrogen produced in the soil after the harvest, but its net rate of production surprisingly decreased. This decrease in net mineralisation is not in agreement with the previous studies from the literature. It appeared that numerous, sometimes antagonistic processes involved in the $\mathrm{N}$-cycle after clear-felling could explain this result: (i) the lack of returns by aboveground litter-fall which eliminate the labile organic compounds, (ii) the intense mineralisation of organic matter from both forest-floor and organo-mineral layers which changed the quality of the organic substrate for decomposers, (iii) the $\mathrm{N}$ immobilisation by the soil micro-organisms leading to an increase in the $\mathrm{N}$ microbial pool, and (iv) a hypothetical role of the developing vegetation changes (Douglas-fir vs. understorey) in the control of the structure of soil micro-organism populations and activity.

In terms of fluxes, decrease in atmospheric deposits, limited returns by the litter from the understorey vegetation, decrease of soil mineral $\mathrm{N}$ production, and significant nutrient uptake by the developing understorey vegetation tended to limit the leaching of $\mathrm{N}$ and cations after the clear-felling. Losses of nutrients $(\mathrm{Ca}, \mathrm{K}$ and $\mathrm{Mg}$ ) and accompanying nitrate in water drainage effectively decreased in the same way in the upper soil horizons after felling. However, $\mathrm{Ca}$ and $\mathrm{Mg}$ fluxes remained more or less unchanged in the deepest horizons indicating no additional losses of nutrients due to leaching. A nutrient budget will be calculated for the whole rotation including the regeneration phase in order to quantify the constraint for the soil.

Further observations will be made to investigate the longterm effects of the harvest on the nitrogen cycle. Key-points to better understand the effect of clear-cutting on forest ecosystem function and sustainability are (i) the role of soil organic matter changes on microbial activity, (ii) the process of fine root turnover after felling (both for cut trees and understorey vegetation), and, (iii) the role of fine roots of vegetation (Douglas-fir vs. understorey) in the control of soil micro-organisms.

Acknowledgements: We would like to thank D. Gelhaye managing the field work, L. Gelhaye and B. Pollier for laboratory analyses, and S. Allié for managing the data bases. B. Jobard from the "Office National des Forêts" provided all the facilities during investigation and sampling. This work received financial support by the Division de l'Espace Rural et des Forêts (Ministère de l'Agriculture), the GIPEcofor and the GESSOL project of the Ministère de l'Écologie et du Développement Durable. We thank Christine Young from the INRA translation service for revising the English.

\section{REFERENCES}

[1] Abacus Concepts Inc., Manuel de référence de StatView, Berkeley, CA, 1996.

[2] Adams M.A., Polglase P.J., Attiwill P.M., Weston C.J., In situ studies of nitrogen mineralisation and uptake in forest soils; some comments on methodology, Soil Biol. Biochem. 21 (1989) 423-429.

[3] Aggangan R.T., O’Connell A.M., McGrath J.F., Dell B., Fertilizer and previous land use effects on $\mathrm{C}$ and $\mathrm{N}$ mineralization in soils from Eucalyptus globulus plantations, Soil Biol. Biochem. 30 (1998) 1791-1798.

[4] Barg A.K., Edmonds R.L., Influence of partial cutting on site microclimate, soil nitrogen dynamics, and microbial biomass in Douglas-fir stands in Western Washington, Can. J. For. Res. 29 (1999) 705-713.

[5] Bobbink R., Roelofs J.G.M., Nitrogen critical loads for natural and semi-natural ecosystems: The empirical approach, Water Air Soil Pollut. 85 (1995) 2413-2418.

[6] Bonne M., Andreux F., Vedy J.C., Souchier B., Étude hydro-chimique saisonnière dans trois sols acides : composition des eaux gravitaires et des solutions extraites à pF 4,4, Sci. Sol 4 (1982) 275-292. 
[7] Bonneau M., Dambrine E., Nys C., Ranger J., Apports acides et cycle des cations dans des pessières du Nord-Est. Intérêt de bilans saisonniers, Sci. Sol 29 (1991) 125-145.

[8] Bormann F.H., Likens G.E., Pattern and Process in a forest ecosystem, Springer Verlag, New York, 1979.

[9] Bormann F.H., Likens G.E., Fischer D.W., Pierce R.S., Nutrient loss accelerated by clear-cutting of a forest ecosystem, Science 159 (1968) 882-884.

[10] Braun-Blanquet J., Plant sociology, the study of plant communities, McGraw-Hill, New York, 1932, reprinted by Koeltz, Koenigstein, 1983.

[11] Brown G.W., Gahler A.R., Marston R.B., Nutrient losses after clear-cut logging and slash burning in the Oregon coast range, Water Resour. Res. 9 (1973) 1450-1453.

[12] Carlyle J.C., Bligh M.W., Nambiar E.K.S., Woody residue management to reduce nitrogen and phosphorus leaching from sandy soil after clear-felling Pinus radiata plantations, Can. J. For. Res. 28 (1998) 1222-1232.

[13] Chang S.X., Preston C.M., Weetman G.F., Soil microbial biomass and microbial and mineralizable $\mathrm{N}$ in a clear-cut chronosequence on northern Vancouver Island, British Columbia, Can. J. For. Res. 25 (1995) 1595-1607.

[14] Chrétien J., Ranger J., Villette S., Modification au cours de la révolution forestière des caractères physiques de sols sous plantations de Douglas (Pseudotsuga menziesii Franco), Étud. gest. Sols 4 (1997) 127-140.

[15] Coats R.N., Leonard R.L., Goldman C.R., Nitrogen uptake and release in a forested watershed, Lake Tahoe Basin, California, Ecology 57 (1976) 995-1004.

[16] Compton J.A., Boone R.D., Long term impacts of agriculture on soil carbon pools and nitrogen dynamics in New England forests, Ecology 8 (2000) 2314-2330.

[17] Cortina J.,Vallejo V.R., Effects of clearfelling on forest floor accumulation and litter decomposition in a radiata pine plantation, For. Ecol. Manage. 70 (1994) 299-310.

[18] Davidson E.A., Swank W.T., Environmental parameters regulating gaseous nitrogen losses from two forested ecosystems via nitrification and denitrification, Appl. Environ. Microbiol. 52 (1986) 1287 1292.

[19] De Boer W., Klein Gunnewiek P.J.A., Troelstra S.R., Nitrification in Dutch heathland soils, II, Characteristics of nitrate production, Plant Soil 127 (1990) 193-200.

[20] Decourt N., Le Douglas dans le Nord-Est du Massif Central, Ann. Sci. For. 24 (1967) 45-84.

[21] Driscoll C.T., Schaefer D.A., Overview of nitrogen processes, in: Malanchuk J.L., Nilsson I. (Eds.), The role of nitrogen in the acidification of soils and surface waters, 1989, pp. 4-1-4-12.

[22] Entry J.A., Stark N.M., Loewenstein H., Effects of timber harvesting on microbial biomass fluxes in a northern Rocky Mountain forest soil, Can. J. For. Res. 16 (1986) 1076-1081.

[23] Ezzaïm A., Intérêt de la mesure du flux d'éléments issu de l'altération des minéraux des sols dans le calcul des bilans minéraux d'un écosystème forestier. Le cas des plantations de Douglas dans le Beaujolais (France), Ph.D. thesis University of Nancy I, 1997.

[24] Fahey T.J., Hughes J.W., Pu M., Arthur M.A., Root decomposition and nutrient flux following whole-tree harvest of northern hardwood forest, For. Sci. 34 (1988) 744-768.

[25] Feger K.H., Nitrogen cycling in two Norway spruce (Picea abies) ecosystems and effects of a $\left(\mathrm{NH}_{4}\right)_{2} \mathrm{SO}_{4}$ addition, Water Air Soil Pollut. 61 (1992) 295-307.

[26] Flinn D.W., Comparison of establishment methods for Pinus radiata on a former $P$. pinaster site, Aust. For. 41 (1978) 167-176.

[27] Giblin A.E., Laundre J.A., Nadelhoffer K.J., Shaver G.R., Measuring nutrient availability in arctic soils using ion exchange resins: A field test, Soil Sci. Soc. Am. J. 58 (1994) 1154-1162.

[28] Granier A., Breda N., Biron P., Villette S., A lumped water balance model to evaluate the duration and intensity of drought constraints of forest soils, Ecol. Model. 116 (1999) 269-283.

[29] Grundmann G.L., Renault P., Rosso L., Bardin R., Differential effects of soil water content and temperature on nitrification and aeration, Soil Sci. Soc. Am. J. 59 (1995) 1342-1349.
[30] Gundersen P., Mass balance approaches for establishing critical loads for nitrogen in terrestrial ecosystems, in: Grennfelt P., Thörnelöf E. (Eds.), Critical loads for nitrogen, a workshop report, Nordic Council of Ministers, 1992, pp. 55-110.

[31] Gundersen P., Emmett B.A., Kjønaas O.J., Koopmans C.J., Tietema A., Impact of nitrogen deposition on nitrogen cycling in forests: a synthesis of NITREX data, For. Ecol. Manage. 101 (1998) 37-55.

[32] Harvey A.E., Jurgensen M.F., Larsen M.J., Ecology of ectomycorrhizae in northern Rocky Mountain forests, in: USDA For. Serv. Gen. Tech. Rep. INT-90, Environmental consequences of timber harvesting in Rocky Mountain coniferous forests: Symposium proceedings, 1980 , pp. 188-210.

[33] Hatch D.J., Jarvis S.C., Phillips L., Field measurement of nitrogen mineralisation using soil core incubation and acetylene inhibition of nitrification, Plant Soil 124 (1990) 97-107.

[34] Hendrickson O.Q., Chatarpaul L., Robinson J.B., Effects of two methods of timber harvesting on microbial processes in forest soil, Soil Sci. Soc. Am. J. 49 (1985) 739-746.

[35] Holmes W.E., Zak D.R., Soil microbial control of nitrogen loss following clear-cut harvest in northern hardwood ecosystems, Ecol. Appl. 9 (1999) 202-215.

[36] Hornung M., Reynolds B., The effects of natural and anthropogenic environmental changes on ecosystem processes at the catchment scale, Trees 10 (1995) 443-449.

[37] Hübner C., Redl G., Wurst F., In situ methodology for studying Nmineralization in soils using anion exchange resins, Soil Biol. Biochem. 23 (1991) 701-702.

[38] Hunt G.A., Fogel R.A., Direct measurement of ectomycorrhizal biomass, in: R. Molina (Ed.), Proceedings of the 6th North American Conference on Mycorrhizae, June 25-29 1984, Bend, Oregon, USA, 1985.

[39] Josserand A., Bardin R., Nitrification en sol acide. I. Mise en évidence de germes autotrophes nitrifiants (genre Nitrobacter) dans un sol forestier sous résineux, Rev. Ecol. Biol. Sol 18 (1981) 435-445.

[40] Jussy J.H., Minéralisation de l'azote, nitrification et prélèvements radiculaires dans différents écosystèmes forestiers sur sol acide. Effets de l'essence, du stade de développement du peuplement et de l'usage ancien des sols, Ph.D. thesis, University of Nancy I, 1998.

[41] Jussy J.H., Colin-Belgrand M., Ranger J., Production and root uptake of mineral nitrogen in a chronosequence of Douglas-fir (Pseudotsuga menziesii) in the Beaujolais Mounts, For. Ecol. Manage. 128 (2000) 197-209.

[42] Jussy J.H., Koerner W., Moares C., Dambrine E., Dupouey J.L., Zeller B., Benoît M., Influence de l'usage ancien des sols sur le cycle de l'azote dans les forêts vosgiennes, Étud. Gest. Sols, 2001, pp. 91-102.

[43] Jussy J.H., Koerner W., Dambrine E., Dupouey J.L., Benoît M., Influence of former agricultural land use on net nitrate production in forest soils, Eur. J. Soil Sci. 53 (2002) 367-374.

[44] Kaiser E.A., Heinemeyer O., Temporal changes in $\mathrm{N}_{2} \mathrm{O}$-losses from two arable soils, Plant Soil 181 (1996) 57-63.

[45] Klemedtsson L., Svensson B.H., Rosswall T., Relationships between soil moisture content and nitrous oxide production during nitrification and denitrification, Biol. Fertil. Soils 6 (1988) 106-111.

[46] Lemée G., Investigations sur la minéralisation de l'azote et son évolution annuelle dans des humus forestiers in situ, Ecol. Plant 2 (1967) 319-324.

[47] Likens G.E., Bormann F.H., Pierce R.S., Reiners W.A., Recovery of a deforested ecosystem, Science 199 (1978) 491-496.

[48] Lossaint P., Rapp M., Sur la minéralisation de l'azote organique d'un humus lent forestier à la suite d'un labour, C. R. Acad. Sci. 251 (1960) 3034-3036.

[49] Lundgren B., Bacteria in a pine forest soil as affected by clear-cutting, Soil Biol. Biochem. 14 (1982) 537-542.

[50] McColl J.G., Retention of soil water following forest cutting, Soil Sci. Soc. Am. J. 41 (1977) 984-988.

[51] McColl J.G., Ionic composition of forests soil solutions and effects of clearcutting, Soil Sci. Soc. Am. J. 42 (1978) 358-363.

[52] Magill A., Aber J., Hendricks J., Bowden R., Melillo J., Steudler P., Biogeochemical response of forest ecosystems to simulated chronic nitrogen deposition, Ecol. Appl. 7 (1997) 402-415. 
[53] Marques R., Dynamique du fonctionnement minéral d'une plantation de Douglas (Pseudotsuga menziesii (Mirb.) Franco) dans les monts du Beaujolais (France), Ph.D. thesis Engref, 1996.

[54] Marques R., Ranger J., Nutrient dynamics in a chronosequence of Douglas-fir (Pseudotsuga menziesii (Mirb.) Franco) stands on the Beaujolais Mounts (France). 1. Qualitative approach, For. Ecol. Manage. 91 (1997) 255-277.

[55] Marques R., Ranger J., Gelhaye D., Pollier B., Ponette Q., Gœdert O., Comparison of chemical composition of soil solutions collected by zero-tension lysimeters with those from ceramic-cup lysimeters in a forest soil, Eur. J. Soil Sci. 96 (1996) 407-417.

[56] Marques R., Ranger J., Villette S., Granier A., Nutrient dynamics in a chronosequence of Douglas-fir (Pseudotsuga menziesii (Mirb.) Franco) stands on the Beaujolais Mounts (France). 2. Quantitative approach, For. Ecol. Manage. 92 (1997) 167-197.

[57] Mulder J., Nilsen P., Stuanes A.O., Huse M., Nitrogen pools and transformations in Norwegian forest ecosystems with different atmospheric inputs, Ambio 26 (1997) 273-281.

[58] Nadelhoffer K., Aber J., Melillo J., Fine roots, net primary production, and soil nitrogen availability: a new hypothesis, Ecology 66 (1985) 1377-1390.

[59] Nohrstedt H.Ö., Sikström U., Ring E., Näsholm T., Högberg P., Persson T., Nitrate in soil water in three Norway spruce stands in southwest Sweden as related to N-deposition and soil, stand, and foliage properties, Can. J. For. Res. 26 (1996) 836-848.

[60] Paavolainen L., Kitunen V., Smolander A., Inhibition of nitrification in forest soil by monoterpenes, Plant Soil 205 (1998) 147-154.

[61] Pennock D.J., van Kessel C., Clear-cut forest harvest impacts on soil quality indicators in the mixedwood forest of Saskatchewan Canada, Geoderma 75 (1997) 13-32.

[62] Persson T., Wirén A., Nitrogen mineralization and potential nitrification at different depths in acid forest soils, Plant Soil 168-169 (1995) 55-65

[63] Pietikäinen J., Fritze H., Clear-cutting and prescribed burning in coniferous forest: comparison of effects on soil fungal and total microbial biomass, respiration activity and nitrification, Soil Biol. Biochem. 27 (1995) 101-109.

[64] Powers R.F., Nitrogen mineralization along an altitudinal gradient: Interactions of soil temperature, moisture, and substrate quality, For. Ecol. Manage. 30 (1990) 19-29.

[65] Raison R.J., Connell M.J., Khanna P.K., Methodology for studying fluxes of soil mineral-N in situ, Soil Biol. Biochem. 19 (1987) 521530.

[66] Ranger J., Gelhaye D., Belowground biomass and nutrient content in a 47-year-old Douglas-fir plantation, Ann. For. Sci. 58 (2001) 423-430.

[67] Ranger J., Marques R., Colin-Belgrand M., Flammang N., Gelhaye D., The dynamics of biomass and nutrient accumulation in a Douglas-fir (Pseudotsuga menziesii Franco) stand studied using a chronosequence approach, For. Ecol. Manage. 72 (1995) 167-183.

[68] Ranger J., Marques R., Colin-Belgrand M., Nutrient dynamics during the development of a Douglas-fir (Pseudotsuga menziesii Mirb.) stand, Acta Ecol. 18 (1997) 73-90.

[69] Ranger J., Marques R., Gelhaye D., Bienaimé S., Gelhaye L., Pollier B., Koerner W., La dynamique du fonctionnement minéral d'une plantation de Douglas (Pseudotsuga menziesii Franco) dans le Beaujolais, Ecologie 29 (1998) 411-415.

[70] Ranger J., Allié S., Gelhaye D., Pollier B., Turpault M.P., Granier A., Nutrient budgets calculated for a rotation of a Douglas-fir plantation in the Beaujolais (France). Conclusions after six years of measurements in a chronosequence of stands, For. Ecol. Manage. 171 (2002) 3-16.

[71] Ranger J., Gérard F., Lindemann M., Gelhaye D., Gelhaye L., Dynamics of litterfall in a chronosequence of Douglas-fir (Pseudotsuga menziesii Franco) stands in the Beaujolais mounts (France), Ann. For. Sci. 60 (2003) 475-488.

[72] Ross D.J., Sparling G.P., Burke C.M., Smith C.T., Microbial biomass $\mathrm{C}$ and $\mathrm{N}$, and mineralizable- $\mathrm{N}$, in litter and mineral soil under Pinus radiata on a coastal sand: Influence of stand age and harvest management, Plant Soil 175 (1995) 167-177.
[73] Sierra J., Temperature and soil moisture dependance of N mineralization in intact soil cores, Soil Biol. Biochem. 9/10 (1997) 15571563.

[74] Smolander A., Priha O., Paavolainen L., Steer J., Mälkönen E., Nitrogen and carbon transformations before and after clear-cutting in repeatedly N-fertilized and limed forest soil, Soil Biol. Biochem. 30 (1998) 477-490.

[75] Soil Survey Staff, Soil Taxonomy, USDA Conservation Service, US Government Printing Office, Washington DC, 1975.

[76] Staaf H., Berg B., Plant litter input to soil, in: Clarke F.E., Rosswall T. (Eds.), Terrestrial Nitrogen Cycles, Ecol. Bull. Stockholm 33, 1981, pp. 147-162.

[77] Stober C., George E., Persson H., Root Growth and Response to Nitrogen, in: Schulze E.D. (Ed.), Carbon and nitrogen cycling in european forest ecosystems, Ecol. Stud. 142, Springer, Berlin, 2000, pp. 99-121.

[78] Stone E.L., The impact of timber harvest on soil and water, in: Government printing office (Ed.), Report of the president's advisory panel on timber and the environment, Washington, DC, USA 1973, pp. 427-467.

[79] Sundman V., Huhta V., Niemela S., Biological changes in northern spruce forest soil after clear-cutting, Soil Biol. Biochem. 10 (1978) 393-397.

[80] Tamm C.O., Nitrogen in terrestrial ecosystems, Ecol. Stud. 81 (1991) $1-115$

[81] Tietema A., Warmerdam B., Lenting E., Riemer L., Abiotic factors regulating nitrogen transformations in the organic layer of forest soils: Moisture and pH, Plant Soil 147 (1992) 69-78.

[82] Ulrich B., Interaction of forest canopies with atmospheric constituents: $\mathrm{SO}_{2}$, alkali and earth alkali cations and chloride, in: Ulrich B., Pankrath J. (Eds.), Effects of accumulation of air pollutants in forest ecosystems, D. Reidel Publish., Dordrecht, 1983, pp. 33-45.

[83] Ulrich E., Lanier M., Combes C., RENECOFOR - Dépôts atmosphériques, concentrations dans les brouillards et dans les solutions du sol (sous-réseau CATANEAT) - Rapport scientifique sur les années 1993 à 1996, Office National des Forêts, Département des Recherches Techniques, 1998, 135 p.

[84] Villette S., Établissement du bilan hydrique sur une chronoséquence de Douglas (Pseudotsuga menziesii (Mirb.) Franco) du Beaujolais. Essai de modélisation, Mémoire de fin d'études de l'ENITA, 1994, $50 \mathrm{p}$.

[85] Vitousek P.M., Clear-cutting and the nitrogen cycle, in: Clarke F.E., Rosswall T. (Eds.), Terrestrial Nitrogen Cycles, Ecol. Bull. Stockholm 33, 1981, pp. 631-642.

[86] Vitousek P.M., Matson P.A., Mechanisms of nitrogen retention in forest ecosystems: a field experiment, Science 225 (1984) 51-52.

[87] Vitousek P.M., Melillo J.M., Nitrate losses from disturbed ecosystems: Patterns and mechanisms, For. Sci. 25 (1979) 605-619.

[88] Vitousek P.M., Reiners W.A., Ecosystem succession and nutrient retention: An hypothesis, Bioscience 25 (1975) 376-381.

[89] Vitousek P.M., Gosz J.R., Grier C.C., Melillo J.M., Reiners W.A., A comparative analysis of potential nitrification and nitrate mobility in forest ecosystems, Ecol. Monogr. 52 (1982) 155-177.

[90] Vitousek P.M., Matson P.A., Van Cleve K., Nitrogen availability and nitrification during succession: Primary, secondary, and oldfield seres, Plant Soil 115 (1989) 229-239.

[91] Walley F.L., Van Kessel C., Pennock D.J., Lanscape-scale variability of $\mathrm{N}$ mineralization in forest soils, Soil Biol. Biochem. 28 (1996) 383-391.

[92] Weetman G.F., Establishment report on a humus decomposition experiment, Woodland Research Index 134, Pulp and Paper Research Institute of Canada, Montreal, 1962.

[93] Wiklander G., Clear-cutting and the nitrogen cycle. Heterogeneous nitrogen leaching after clear-cutting, in: Clarke F.E., Rosswall T. (Eds.), Terrestrial Nitrogen Cycles, Ecol. Bull. Stockholm 33, 1981, pp. 642-647.

[94] Wyland L.J., Jackson L.E., Evaluating nitrate recovery by ionexchange resin bags, Soil Sci. Soc. Am. J. 57 (1993) 1208-1211. 